DOI https://doi.org/10.18551/rjoas.2017-09.24

\title{
THE ROLE OF FINANCIAL LITERACY IN CREATIVE INDUSTRY GROWTH: WOMEN ENTREPRENEUR STUDY OF DONGGALA WOVEN FABRIC INDUSTRY
}

\author{
Tallesang Mukhtar*, Rossanty Niluh Putu Evvy, Darman \\ Faculty of Economics, Tadulako University, Indonesia \\ *E-mail: $\underline{\text { m.tallesang@gmail.com }}$
}

\begin{abstract}
Having a financial literacy is vital to get a prosperous life. Proper financial management supported by good financial literacy is expected to increase the standard of living. This term is applied to every income level as no matter how much someone's income level is, without having good financial management, it is surely hard to achieve financial security. This study aims to (1) analyze factors affecting women entrepreneur financial literacy of Donggala woven fabric creative industry player, (2) analyze the role of financial literacy in creative industry growth. The object of this study was 34 women entrepreneur selected randomly. The data were analyzed using multiple regression analysis. The result shows that the factor of education (sig. 0.883), age (sig. 0.494), and the length of business (0.383) has no significant influence on the level of women entrepreneur financial literacy of Donggala woven fabric creative industry player ( $\alpha$ : 0.05). Except for training financial factor (sig. 0.002), it has a significant influence on the level of women entrepreneur financial literacy. The same goes to the financial literacy (sig. 0.001) having significant influence over the creative industry growth of Donggala woven fabric in Central Sulawesi-Indonesia.
\end{abstract}

\section{KEY WORDS}

Creative industry, financial literacy, women entrepreneur, donggala woven fabric.

Arranging an effective financial decision and understanding how to manage money is a key skill to enjoy financial in the future. However, there are many individuals and families who do not have an understanding required to make a good financial decision (Braunstein et al., 2002). Financial distress is influenced not only by earned income, but also mismanagement. Understanding financial literacy is vital to get a prosperous life. Proper financial management supported by good financial literacy is expected to increase the standard of living. This term is applied to every income level as no matter how much someone's income level is, without having good financial management, it is surely hard to achieve financial security.

A research on financial literacy at SMEs (Usaha Kecil Menengah or UKM) in Ghana finds that financial literacy is essential to encourage SMEs sector (Nunoo et al., 2012). The result shows that financial literacy has a positive influence over the SMEs performance. George Lucas Educational Foundation (2013) proposes that financial literacy is essential to enable individual to make a financial decision, to discuss financial issues and the future plan.

One of the SMEs passed down over the generation by the community of Donggala district is the creative industry of Donggala woven fabric. This traditional woven fabric is really unique since made of natural silk fibers with various colors and pattern which is truly interesting and typical and is weaved by the ingenious hand of rural women using traditional equipment called balida (traditional loom). However, nowadays, the creative industry of Donggala woven fabric suffers in a downturn and even feared extinct. One of the causes is the women of Donggala woven fabric creative industry player still have a limitation of knowledge and financial management.

Considering the importance of financial literacy to the community, especially women entrepreneur, as well as the importance of preserving Donggala woven fabric in Central Sulawesi, it is important to analyze factors affecting financial literacy and the role of financial literacy in creative industry business growth of Donggala woven fabric. 


\section{LITERATURE REVIEW}

Greenspan (2002) states that financial literacy helps individual to understand financial knowledge needed to arrange household budget, to start saving the plan, and to make a strategic investment decision. The right application will help an investor to fulfill his/her financial obligation through thoughtful training and resources allocation can decrease maximum utility. Lusardi and Mitchell (2007) define financial literacy as the financial knowledge and ability to apply it. Additionally, The President's Advisory Council of Financial Literacy (2008) also defines financial literacy as the ability to function knowledge and ability to manage financial resources to achieve prosperously.

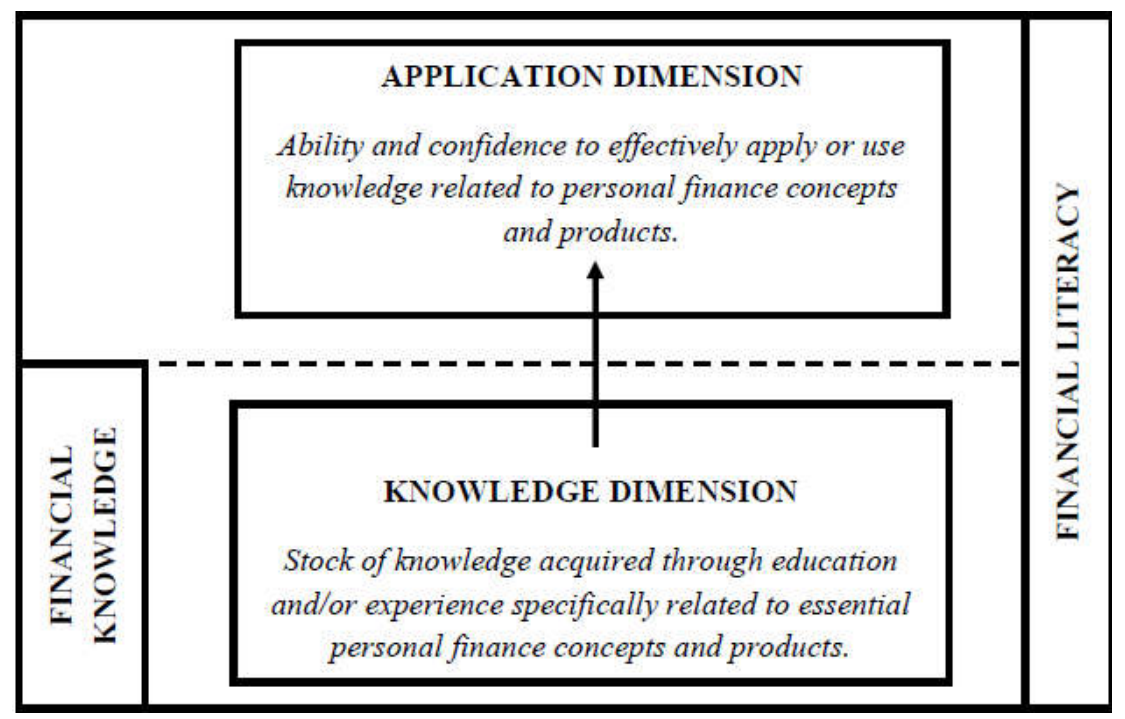

Figure 1 - Financial Literacy Concept (Hutson, 2011)

Huston (2010) proposes that financial literacy can be defined as the measurement how well an individual is to understand and use information related to the financial. Financial literacy needs not only knowledge dimension but also additional dimension-that is, application dimension that requires individual to have an ability and self-confidence of financial literacy owned to be used in the financial decision making. Such literacy concept is illustrated in figure 2.1.

Chen and Volpe (1998) define financial literacy as the ability to manage finance to get a prosperous life in the future. There are four aspects of financial literacy, firstly General Personal Finance Knowledge covering to an understanding of several things related to the basic knowledge of financial. Secondly, Savings and Loans, these cover to knowledge related to the savings and loans. Thirdly, insurance, it covers to insurance basic knowledge and basic insurance. Fourthly, Investments covering to knowledge on investment and investment risk. Additionally, Remund (2010) states that there are 4 most common things in financial literacy, that is: unemployment, savings, loans, and investment. Financial literacy involves not only knowledge and ability to overcome a problem but also a non-cognitive attribute.

According to the Financial Services Authority (Otoritas Jasa Keuangan or OJK) (2013), literacy is defined as the ability to understand, thus financial literacy is the ability to manage fund owned to get a more prosperous life in the future. OJK states that the important mission of financial literacy program is to educate the community to manage financial smartly and to overcome the low financial literate in order to achieve more prosperous life. For that matter, OJK launches three main pillars of financial literacy, that is: Pillar 1, education and national campaign on financial literacy. Pillar 2, reinforcement of financial literacy infrastructures. Pillar 3, financial services and products development. The performance of those three pillars is expected to be able to realize Indonesian society having high financial literacy so they will have financial knowledge and apply it to increase prosperous. 


\section{METHODS OF RESEARCH}

This was quantitative descriptive research using survey methods. The object of this study was Donggala woven fabric creative industry in Central Sulawesi-Indonesia. While the analysis unit of this study was the women of Donggala woven fabric creative industry player, 34 of them were chosen randomly as the sample. Analysis methods used was consisted of 2 stages, namely:

Identifying factors influencing women financial literacy of Donggala woven fabric creative industry player. The data was analyzed using inferential statistic in form of multiple regression analysis (Algifari, 1997) using SPSS 16 statistics.

$$
Y=a+b 1 \times 1+\ldots b n \times n+e
$$

Where: Y - Financial Literacy (dependent variable); a - Intercept variable; b1...bn Regression coefficient; $x 1$...xn - Influencing factors (independent variable); e - error.

Identifying the role of financial literacy in creative industry growth of Donggala woven fabric. Creative industry growth uses an indicator of selling growth, capital growth, asset growth, and profit growth (Musran, 2010).

$$
Y(\text { Creative industry growth })=a+b \text { Financial Literacy }+e
$$

\section{RESULTS AND DISCUSSION}

The result of data processing using multiple regression linear analysis aiming to know factors influencing the level of women entrepreneur financial literacy of Donggala woven fabric craftsmen is as follow:

Table 1 - Value for R-squared model

\begin{tabular}{|c|c|cc|}
\hline Model & $\mathrm{R}$ & Adjusted R-squared \\
\hline 1 & $.881^{\mathrm{a}}$ & & .767 \\
\hline a. Predictors: (Constant), Training, Age, Education, Long Business & \\
\hline
\end{tabular}

Source: Processed Data, 2017.

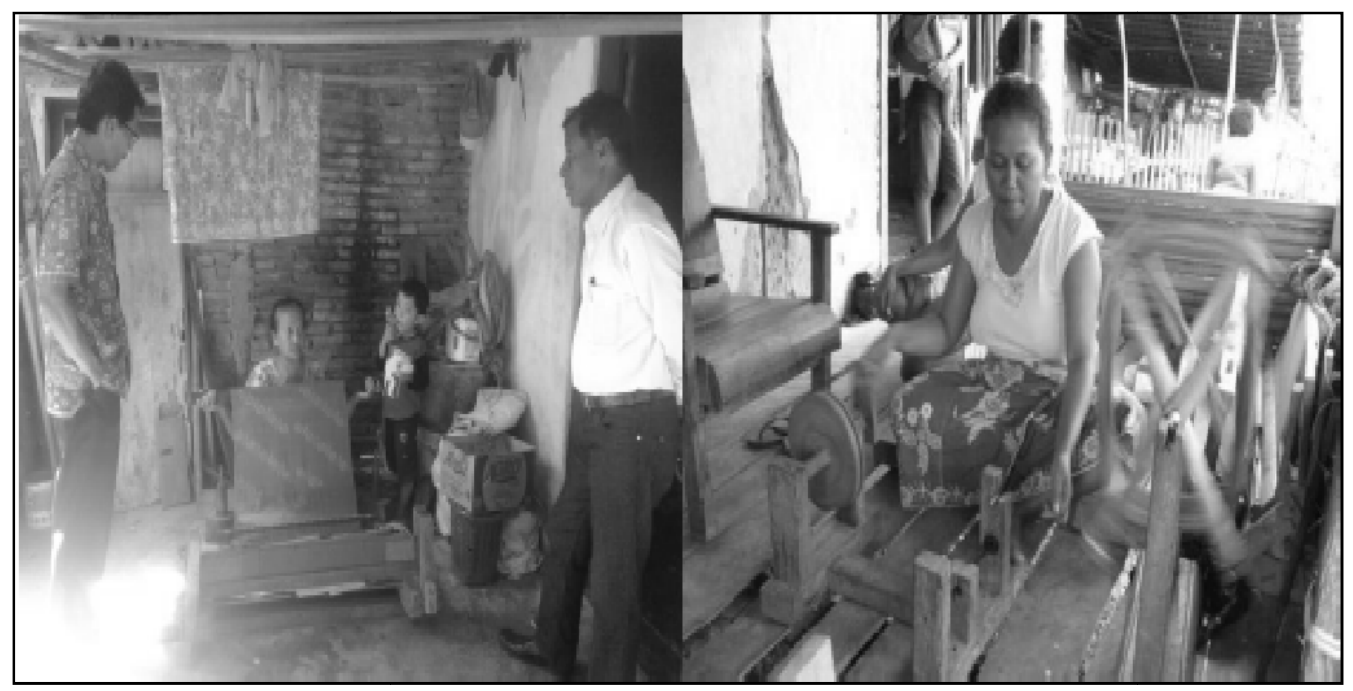

Figure 2 - Women Entrepreneur of Donggala Woven Fabric Creative Industry Player

Factor influence testing of financial training, age, education, and the length of business results in the value of $R$ by 0.881 . It shows that the relationship between financial training, age, education, and long business and the level of women entrepreneur financial literacy is categorized as strong. Moreover, the existence of Adjusted-R Squared value by 0.767 
indicating that the variable factor of financial training, age, education, and the length of business is able to explain the level of women entrepreneur financial literacy by 76.7 percent, while 23.3 is explained by other factors out of the model.

According to the model reliability of Table 1 above, thus performed testing between the independent variable (financial training, age, education, and long business) and the dependent variable (financial literacy level).

The result of data processing is seen from Table 2.

Table 2 - Data processing Result of Influencing Factors Women Entrepreneur Financial Literacy

\begin{tabular}{|c|c|c|c|c|c|c|}
\hline \multirow{2}{*}{\multicolumn{2}{|c|}{ Model 1}} & \multicolumn{2}{|c|}{ Unstandardized Coefficients } & \multirow{2}{*}{$\frac{\text { Standardized Coefficients }}{\text { Beta }}$} & \multirow{2}{*}{$\mathrm{t}$} & \multirow{2}{*}{ Sig. } \\
\hline & & $\mathrm{B}$ & Std. Error & & & \\
\hline \multirow{5}{*}{$\mathrm{n} / \mathrm{n}$} & (Constant) & .338 & .878 & & .385 & .703 \\
\hline & Education & .019 & .131 & .024 & .148 & .883 \\
\hline & Age & .111 & .161 & .113 & .693 & .494 \\
\hline & Long Business & .124 & .140 & .148 & .885 & .383 \\
\hline & Financial Training & 1.022 & .292 & .560 & 3.498 & .002 \\
\hline \multicolumn{6}{|c|}{ a. Dependent Variable: Financial Literacy ( $\alpha$ : 0.05) } & \\
\hline
\end{tabular}

Source: Processed Data, 2017.

According to the result of data processing, it shows that the factor of education (sig. 0.883), age (sig. 0.494), the business (0.383) has no significant influence on the level of women entrepreneur financial literacy of Donggala woven fabric creative industry player. Except for training financial factor (sig. 0.002), it has a significant influence on the level of women entrepreneur financial literacy.

Education factor has no significant influence over the women entrepreneur financial literacy level. It is caused by the low educational background of women entrepreneur of Donggala woven fabric creative industry player. Educational background of women entrepreneur is not graduate primary school ( $<S D$ ) by 23,5 percent, graduate SD by 47.1 percent, graduate Junior High School (SMP) by 20.6 percent, and graduate Senior High School (SMA) by 8.8 percent. This indicates that most women entrepreneur of Donggala woven fabric creative industry player have a low educational background so never had a lesson about financial knowledge formally.

Age has no significant influence over the women entrepreneur financial literacy level. The age of women entrepreneur ranging from 20-35 years old is 23.5 percent, 36-45 years old by 26.5 percent, and above 46 years old by 50 percent. This indicates that the majority of women entrepreneur of creative industry player is elderly. Commonly, women entrepreneur are a housewife who not only does housework but also manages a business to get more income.

The length of a business factor also has no significant influence on the level of women entrepreneur financial literacy. The length of time of Donggala woven fabric creative industry less than 5 years is 25.5 percent, while those which have been running for $6-15$ years are 27.5 percent, and those above 15 years are 47.1 percent. This indicates that, generally, Donggala woven fabric creative industry has been managed for a long time and passed down from the generation by women entrepreneur, but its financial management suffering in stagnancy.

Financial training factor has a significant influence on the level of financial literacy of women entrepreneur. Training on business financial management held by local government along this time actually plays an important role in the level of women entrepreneur financial literacy of Donggala woven fabric creative industry player. However, it is only sub-section of women entrepreneur who gets training on business financial management. Survey result indicates that women entrepreneur who gets financial training is only 17.6 percent, while the 82.4 percent do not participate yet.

Moreover, data processing was done to find out the role of financial literacy in creative industry growth of Donggala woven fabric. The result of data processing is depicted from Table 3. 
Table 3 - Data Processing Result of Financial Literacy Role in Creative Industry Growth

\begin{tabular}{|c|c|c|c|c|c|c|}
\hline \multicolumn{2}{|c|}{ Model 1 } & \multicolumn{2}{c|}{ Unstandardized Coefficients } & Standardized Coefficients & \multirow{2}{*}{$\mathrm{t}$} & \multirow{2}{*}{ Sig. } \\
\cline { 3 - 6 } & B & Std. Error & Beta & 2.803 & .009 \\
\hline \multirow{2}{*}{$\mathrm{n} / \mathrm{n}$} & (Constant) & .814 & .291 & .536 & 3.594 & .001 \\
\cline { 2 - 7 } & Financial Literacy & .621 & .173 & & & \\
\hline \multicolumn{2}{|l|}{ a. Dependent Variable: Growth of age }
\end{tabular}

Source: Processed Data, 2017.

Table 3 above indicates that financial literacy (sig. 0.001) has a significant influence on the creative industry growth of Donggala woven fabric in Central Sulawesi-Indonesia. This indicates that financial literacy in form of financial basic knowledge, knowledge of savings and loan, knowledge of assurance, and knowledge of investment very influences the sustainability of Donggala woven fabric creative industry which is the cultural heritage of Central Sulawesi community-Indonesia.

\section{CONCLUSION}

According to the explanation above, it concludes that financial training delivers values to the level of women entrepreneur financial literacy of Donggala woven fabric creative industry player. Additionally, financial literacy in form of basic knowledge of financial, knowledge of savings and loans, knowledge of assurance, and knowledge of investment has a big influence over the sustainability of Donggala woven fabric creative industry which is the cultural heritage of Central Sulawesi community-Indonesia. For that matter, women entrepreneur are expected to increase their financial literacy and contribution to the related sides, especially the local government to perform efforts to increase the financial literacy of creative industry player, especially financial training administration.

\section{REFERENCES}

1. Algifari, 1997. Analisis Statistik Untuk Bisnis; Dengan Regresi, Korelasi dan Nonparametrik, Yogyakarta: BPFE

2. Braunstein, Sandra and Carolyn Welch, 2002. Financial Literacy: An Overview of Practice, Research and Policy. Federal Reserve Bulletin, Federal Reserve Board.

3. Chen, H. \& Volpe, R. P. 1998. An analysis of personal financial literacy among college students, Financial Services Review, 7(2): 107-128.

4. George Lucas Educational Foundation, 2013. How Financial Literacy Yields Success.

5. Greenspan, A., 2002. A Tool for Economic Progress, the Futurist, 4(36): 37- 41.

6. Huston, S. J., 2011. Measuring Financial Literacy, Rochester: SSRN Paper Series.

7. Huston, S.J., 2010. Measuring Financial Literacy, Journal of Consumer Affairs, 2(44).

8. Lusardi, A., Mitchell, O. S., 2007. Financial Literacy and Retirement Planning: New Evidence from the Rand American Life Panel, JEL classification: D91

9. Musran, T. M., 2010. Pengaruh Faktoe Eksternal dan Internal Kinerja UKM di Sulawesi Selatan, Jurnal Manajemen dan Kewirausahaan, Vol 12 No.1: 33-41.

10. Nunoo dan Andoh, 2012. Sustaining Small and Medium Enterprises through Financial Service Utilization: Does Financial Literacy Matter?

11. Otoritas Jasa Keuangan, 2013. Financial Customer Care, Majalah Edukasi Konsumen, Edisi Agustus 2013, Th. I.

12. Remund, D L., 2010. Financial Literacy Explicated: The Case For A Clearer Definition In An Increasingly Complex Economy. Journal of Consumer Affairs, Volume 44 Issue 2.

13. The President's Advisory Council of Financial Literacy, 2008. Annual Report to the President, Executive Summary.

(c) 2017 by the authors. Licensee RJOAS, Orel, Russia. This article is an open access article distributed under the terms and conditions of the Creative Commons Attribution (CC BY) license: http://creativecommons.org/licenses/by/4.0/ 